\title{
Catherine II as Female Ruler: The Power of Enlightened Womanhood
}

\author{
Victoria Ivleva \\ Durham University \\ viktoria.ivleva@durham.ac.uk
}

\begin{abstract}
:
This article examines some of the complexities of female rule during the reign of Catherine II (17621796). It argues that in addition to the Baroque scenarios of power inherited from her predecessors, the German-born Russian empress employed the cultural roles of an "enlightened" woman of merit - a matriarch, a craftswoman, a house manager, and an educator - roles that projected positive values of womanhood, in order to position her femininity as beneficial to the state and to thereby legitimize her authority as a female sovereign.
\end{abstract}

Keywords:

Catherine II, Peter I, Elizabeth, gender roles, patriarchy, matriarchy, statecraft, housecraft, domesticity, education

Within the two years after Catherine II's accession to the throne in 1762, the Danish artist Vigilius Erichsen (1722-1782) completed painting her famous double portrait (Fig. 1). In the forefront, the Empress of All the Russias appears to step out of her official role as sovereign to pose as a lovely woman. Her delicate shoe, which peeks from under the hem of a large hoop skirt, is one of the details that conveys this impression. Catherine's lively eyes, slightly raised eyebrows, the cut and color of her dress, and a fan in her hand, create flattering allusions to the graceful portraits of the younger Grand Duchess, painted two decades earlier by Erichsen's predecessor, Georg Christoph Grooth (1716-1749). ${ }^{1}$ These allusions are not meant to flatter an aging female monarch, but to underscore the newly-crowned ruler's soft nature and grace. The inclusion of a second, half-length portrait of the empress in the same composition demonstrates the transformation that Catherine underwent after assuming her royal responsibilities. The mirror image presents the empress as a forward-looking stateswoman and a veritable profile in power. ${ }^{2}$ The monarch's attributes of rule, however, emphasize both the duality and the unity of her roles. Thus the scepter becomes a continuation of her half-opened fan, with both objects

I would like to thank Andy Byford, Alexander Dolinin, Daria Khitrova, Ilya Kliger, Gary Marker, Boris Maslov, Vera Proskurina, Mark Steinberg, and Ernest Zitser for their valuable suggestions at different stages of my work on this article. The article was originally presented at the Slavic colloquium in New York University (2012) and I am grateful to colleagues for their contributions. This paper has also greatly benefited from the generous comments of anonymous reviewers. All translations are mine unless otherwise noted.

${ }^{1}$ Georg Christoph Grooth, Portrait of Grand Duchess Ekaterina Alekseevna (circa 1745). Oil on canvas, $105 \times 85 \mathrm{~cm}$. State Hermitage Museum, St. Petersburg, Russia.

${ }^{2}$ Similar profile images of the empress were replicated in busts, on coins, cameos, medallions, and decorative plates. 
pointing towards her regal image, while the interplay of these images and the empress' mirrored representation symbolize an act of transcendence. ${ }^{3}$

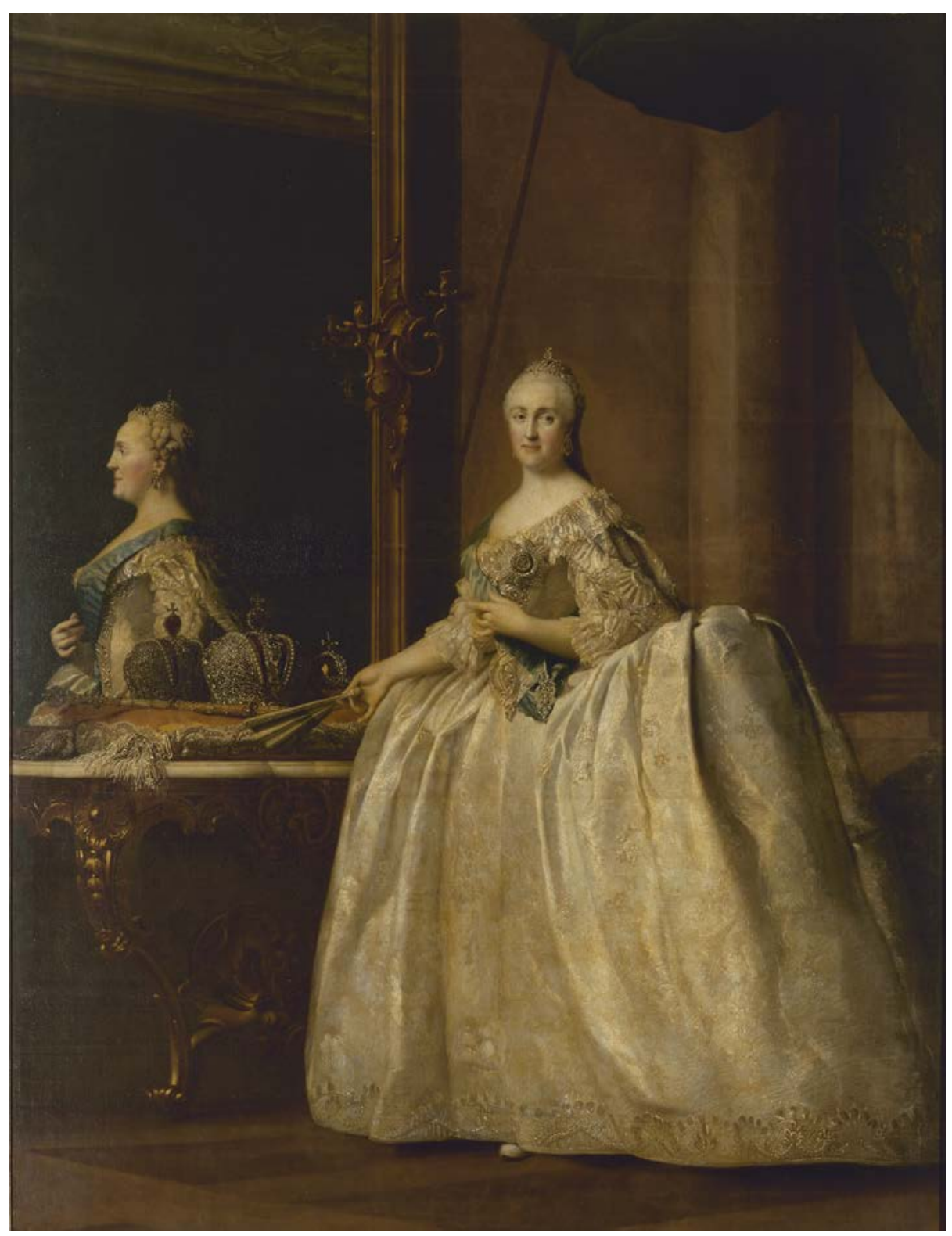

Figure 1: Copy of an original painting by Vigilius Erichsen, Portrait of Catherine II in Front of a Mirror. Oil on canvas. 262.5X201.5 cm. Denmark, Between 1762-1764

(c) The State Hermitage Museum, St. Petersburg (Photo by Vladimir Terebenin)

Erichsen, who was one of the most prolific portraitists of Catherine II, drastically departed here from his earlier representation of the empress on

\footnotetext{
${ }^{3} \mathrm{Cf}$. the discussion of the ambiguous and dynamic relationship between these two representations, in Luba Golburt, The First Epoch: The Eighteenth Century and the Russian Cultural Imagination (Madison: U of Wisconsin P, 2014), 59-62.
} 
horseback in the uniform of the Preobrazhensk (Transfiguration) Life Guards Regiment, which he painted soon after the coup of $1762 .{ }^{4}$ This earlier, equestrian portrait had emphasized the Grand Duchess' personal bond with Peter I's favorite military division. This bond not only helped Catherine to ascend the throne, but also to highlight her continuation of Peter I's policies at the time of the coup..$^{5}$ By contrast, in the double portrait, Erichsen chose to focus on Catherine's feminine side, as he depicted the empress in a semi-official setting. He adorned her only with the Order of St. Andrew The First-Called (Protocletus) and left her royal regalia on the table. Two performative roles and two codes of representation-one of a high society lady and the other of a stateswoman-converged in this portrait. ${ }^{6}$

Erichsen's trompe l'oeil addressed, and artistically-resolved, a topical political problem: the wide-spread concern about female rule in general, and Catherine's rule in particular. ${ }^{7}$ Catherine's maternal identity and royal legitimacy had already been seriously undermined at the time of her husband's accession to the throne, when the newly-crowned Emperor Peter III decided not to name their son Paul as his heir. After her husband's dethronement and death, and her reputed lover's rapid social advancement (evident in Grigorii Orlov's ultimately unsuccessful matrimonial plans), ${ }^{8}$ Catherine was criticized for an inability to withstand her passions. ${ }^{9}$ By focusing on the issue of favoritism, European political

\footnotetext{
${ }^{4}$ Vigilius Erichsen, Equestrian Portrait of Catherine II (1762). Oil on canvas, $195 \times 178.3 \mathrm{~cm}$.

${ }^{5}$ On the display of imperial (Petrine) imagery as a crucial attribute of new enthronements that helped to establish the authority of each new eighteenth-century Russian sovereign, see the first volume of Richard S. Wortman, Scenarios of Power: Myth and Ceremony in Russian Monarchy from Peter the Great to the Abdication of Nicholas II (Princeton: Princeton UP, 1995).

${ }^{6}$ A similar division of Catherine's image into different gender identities can be observed in Catherine's first memoir, which was written around 1756. On the one hand, she assigned herself certain male traits (a tomboy's nature and a strong-willed character). On the other, as Hilde Hoogenboom has suggested, the memoir focused on Catherine's fulfillment of her feminine role, as she became a mother of the future heir, the event that secured her position at the court. On the significance of the episode devoted to Paul's birth in the structure of the first memoir, see Hilde Hoogenboom's preface, "Catherine the Great and Her Several Memoirs," in Mark Cruse \& Hilde Hoogenboom, trans., The Memoirs of Catherine the Great (New York: Modern Library, 2005), ixlxix, here xv.

${ }^{7}$ See Brenda Meehan-Waters, "Catherine the Great and the Problem of Female Rule," Russian Review 34:3 (1975): 293-300; and Evgenii Anisimov, "Zhenshchina u vlasti v XVIII v. kak problema," DHI Moskau: Vorträge zum 18. und 19. Jahrhundert, 9 (2011), available online at: http://www.perspectivia.net/content/publikationen/vortraege-moskau/anisimov herrschaft.

${ }^{8}$ On the marriage scheme, see Vasilii A. Bil'basov, Istoriia Ekateriny Vtoroi (Berlin: F. Gottheiner, 1900), 2: 275-96. For a discussion of the struggle between the Bestuzhev-Orlov and Panin groups, see David Ransel, The Politics of Catherinian Russia. The Panin Party (New Haven \& London: Yale UP, 1975), 102-127. On conspiracies during the first stage of Catherine's reign caused by her favoritism, see the Count von Solms' letters to Frederick II of July 1 (12), 1763, July 25 (August 5), June 22 (July 3), 1764, in Sbornik Imperatorskogo Russkogo Istoricheskogo Obshchestva [hereafter SIRIO] 22 (1878): 84, 96-97, 261-62.

${ }^{9}$ See, for example, the following excerpt from Count von Solms' letter to Frederick II of June 7 (18), 1763: "On n'aperçoit en elle que la femme, qui aime le plaisir et la volupté, que tôt ou tard peut se livrer à la discrétion d'un amant et lui abandonner les rênes de l'empire." [They see her as a woman who loves amusements and sensual pleasures, who can, sooner or later, come under her lover's
} 
commentators either denied that Catherine exercised real power or highlighted her deviations from established (patriarchal) norms. As a result, the Russian empress was presented as failing both as a ruler and as a woman. ${ }^{10}$ These misogynistic accounts expressed contemporary concerns about female rule, registered the precarious position of women in power, and presented femininity as a personal weakness that was potentially dangerous to the state rather than as an asset for a female monarch. ${ }^{11}$

As Erichsen's portraits demonstrate, however, in order to reconcile a widely-shared misogyny with the actuality of female rule in eighteenth-century Russia, androgynous identities and male traits were regularly projected onto female sovereigns, including by the female sovereigns themselves. This was certainly the case during the reign of Catherine II. $^{12}$ The projection of an androgynous identity helped the German-born empress to establish her authority at the beginning of her reign and to gain support among the more progressive members of the opposition to Peter III. ${ }^{13}$ The maintenance of power, however,

power and give him the reins of the empire]. SIRIO 22: 73. See also Count Nikita Panin's remark: "Mrs. Orlov would never be Empress of All Russia." According to David Ransel, this criticism was shared by other courtiers. Ransel, The Politics of Catherinian Russia, 125. For a later criticism of Catherine II both as an empress and as a woman, see Mikhail M. Shcherbatov, On the Corruption of Morals in Russia, ed. \& trans. Antony Lentin (London: Cambridge UP, 1969). Shcherbatov blamed the corruption of the Russian court on female rule.

${ }^{10}$ For more examples of criticism of Catherine's royal and feminine qualities, see Adelaide D'arcy Collyer, ed., The Despatches and Correspondence of John, Second Earl of Buckinghamshire, Ambassador to the Court of Catherine II of Russia 1762-1765 (London: Longmans, Green, \& Co., 1900): 1: 67; Claude-Carloman de Rulhière, History or Anecdotes of the Revolution in Russia (New York: Arno Press, 1970); Vincent Carretta, "Petticoats in Power': Catherine the Great in British Political Cartoons," in Kevin L. Cope, ed., 1650-1850: Ideas, Aesthetics, and Inquiries in the Early Modern Era (New York: AMS Press, 1994), 1: 23-81; Ruth Dawson, "Eighteenth-Century Libertinism in a Time of Change: Representations of Catherine the Great," Women in German Yearbook 18 (2002): 67-88; Monica Greenleaf, "Performing Autobiography: The Multiple Memoirs of Catherine the Great (1756-1796)," Russian Review 63.2 (2004): 407-26, particularly 417-18.

${ }^{11}$ In this article, mysogyny is understood as a prejudiced attitude towards women in power, a prejudice that is shared by both men and women in a patriarchal society.

${ }^{12}$ Vera Proskurina has shown that Catherine II and her subjects constructed her public representations by drawing on allusions to female warriors and classical deities, most of which had an androgynous nature. For a discussion of "the attribution of manliness" to Russian empresses after the issuance of Peter I's accession manifesto, see Cynthia Hyla Whittaker, Russian Monarchy. Eighteenth-Century Rulers and Writers in Political Dialogue (DeKalb: Northern Illinois UP, 2003), 65-67. For practices of manly behavior by Russian empresses and noblewomen more generally, see Vera Proskurina, Mify imperii: Literatura i vlast'v epokhu Ekateriny II (Moscow: Novoe literaturnoe obozrenie, 2006), 14-16, 25-27, 30, 32-33, 52-53; and Alexander Woronzoff-Dashkoff, Dashkova: A Life of Influence and Exile (Philadelphia: American Philosophical Society, 2008), 21-22, 49-55, 260. On practices of cross-dressing at Elizabeth's court, and Catherine's emphasis on her own manly traits, see Catherine II, Sochineniia imperatritsy Ekateriny II. Ed. Aleksandr N. Pypin. 12 vols. (St. Petersburg: Tipografiia Imperatorskoi Akademii nauk, 1901-1907): 12: 291, 296-97, 316-17, 360-61, 366. ${ }^{13}$ The construction of a new identity was important for the young German princess since her first days in Russia. Her geographical and cultural relocation, change of name, language, and religion all gave impulse to a conscious narrativization of her life. On Catherine's use of novelistic topoi in her 
depended on her ability to complement these earlier strategies with the projection of a positive feminine identity, one that could appeal to a larger part of the Russian political nation. As this article will demonstrate, Catherine II consciously tried to harmonize the requirements of her royal occupation with the tasks and virtues of womanhood by drawing on analogies between statecraft and housecraft and by projecting favorable representations of herself in the roles of a woman of merit, a matriarch, a craftswoman, a mistress of the household, and an educator. In doing so, she sought to adapt Enlightenment ideals about gender relations to a very different, if no less patriarchal, political context. ${ }^{14}$

\section{A Woman of Sense vs. a Woman of Fashion}

One of the ways that Catherine II sought to present her womanhood positively was to discredit Empress Elizabeth's reign and to disengage herself from Elizabeth's court culture-one that was popularly seen as encouraging luxury and foppishness in emulation of the French court. According to Hans Rogger, Francomania reached its peak in the period between 1755 and $1775 .{ }^{15}$ The number of petits-maitres and petites-maîtresses significantly increased during Elizabeth's reign, but their reception by Russian society, in literary works, and on stage, was highly critical. ${ }^{16}$ Catherine's attitude to Elizabeth's court culture was influenced by the European and Russian anti-luxury discourse that disapproved of conspicuous consumption and was often combined and associated with the traditionally

memoirs for purposes of legitimization and creation of a personal mythology, see Angelina Vacheva, Romanut na Imperatrisata: Romanoviiat diskurs v avtobiografichnite zapiski na Ekaterina II. Rakursi na chetene prez vtorata polovina na XIX vek (Sophia: St. Kliment Okhridski UP, 2008).

${ }^{14}$ The analogy between housecraft and statecraft dates back at least to Aristotle and was by no means unusual in the eighteenth century. Maria Theresa (1717-1780), the only female sovereign from the Habsburg dynasty (1740-1780), projected a similar matriarchal self-image and interwove tropes of statecraft and domesticity in her governance. Yet, her personal circumstances were very different-she was a mother of sixteen children and always had a male co-ruler. See Mary Maxwell Moffat, Maria Theresa (London: Methuen, [1911]), 202-206, 219, 336-39; Constance Lily Morris, Maria Theresa: The Last Conservative (New York: A. A. Knopf, 1937), 153, 155, 157-59, 208, 261, 276, 337; Robert Pick, Empress Maria Theresa: The Earlier Years, 1717-1757 (London: Weidenfeld \& Nicolson, [1966]), 157, 226, 305; and Carlile A. Macartney, Maria Theresa and The House of Austria (London: English Universities Press, 1969), 96, 117, 125, 133.

${ }^{15}$ Hans Rogger, National Consciousness in Eighteenth-Century Russia (Cambridge, MA: Harvard University Press, 1960), 50.

${ }^{16}$ For examples of French plays that portrayed fops and coquettes and were staged by the court theater troupes in 1750-176os, see Aleksei G. Evstratov, "Ekaterina II i russkaia pridvornaia dramaturgiia v 1760-e-nachale 1770-kh godov." (PhD diss., Russian State University for Humanities, 2009), 130-31. Evstratov connects the increase of comic and satirical representations of fops on stage with court politics oriented towards an appreciation of Russian cultural heritage (136). For a further discussion of Catherine's policies and projects directed at re-evaluating Russian history and culture in the context of European cultural developments, as well as the empress's emphasis on self-sufficiency of Russian culture, see Aleksandr D. Ivinskii, Literaturnaia politika Ekateriny II (Moscow: Knizhnyi dom Librokom, 2012), 10-11, 22-28, 30-49, 55, 58, 84, 86-97. 
unfavorable attitude towards women in power. ${ }^{17}$ When discussing Elizabeth's reign in her second memoir (1771-1773), Catherine presented it through images of negative femininity, emphasizing Elizabeth's arbitrariness, penchant for luxury, and self-indulgence. ${ }^{18}$ The German-born empress may also have had preconceived notions against petits-maîtres, in contrast to burghers. While burghers embodied values of good citizenship in the context of state-society relations, fops represented an anti-model of the approved code of social behavior. Her reaction to a report (in French) from the magistrate of Narva, provides a fine illustration of her disapproving attitude towards petits-maitres and, more generally, towards what she perceived to be French cultural behavior. Addressing Field Marshal Münich, the empress wrote:

"You will do me a great pleasure of explaining to them that I would have liked it more if in the future, they wrote in Russian or German to me, for I would rather have good, fat burghers and rich merchants in my towns than petits-maitres. I am afraid that if they use French, they will abide by French morals (...)." 19

The opposition between a petit-maitre/petite-maîtresse (i.e. a wo/man of fashion) and a wo/man of sense (or, more broadly, of merit) was a common subject in the European discourse on luxury, education, and statecraft. ${ }^{20}$ Catherine II made use of both negative and positive capabilities of this cultural opposition, juxtaposing a negative image of Elizabeth as a woman of fashion to her own image as a woman of sense/merit. She highlighted those qualities of her own social identity that helped her redefine femininity in positive terms in the context of the values of both the patriarchal culture in which she lived and of the Enlightenment ideology that she promoted on a state level. The empress accomplished this goal by presenting herself as an industrious and benevolent sovereign, who worked ten to fifteen hours a day, took care of the public good, and was simple in her manners

\footnotetext{
${ }^{17}$ For criticism of luxury, see, for example, Bernard Mandeville, The Fable of the Bees: Or, Private Vices, Publick Benefits (London: printed for J. Roberts, 1714) and Jean-François Marmontel, Bélisaire (Paris: Société des Textes Français Modernes, 1994): 94, 115-16, 140-57. For a discussion of French anti-luxury discourse and changes in the luxury critique after 1750, see John Shovlin, "The Cultural Politics of Luxury in Eighteenth-Century France," French Historical Studies 23.4 (2000): 577-606.

${ }^{18}$ For a discussion of Catherine's assessment of Elizabeth's reign in her second memoir, see Greenleaf, "Performing Autobiography," 418.

19 "Vous me feriez plaisir de leur donner à entendre que j'aimerais mieux qu'ils se servent à l'avenir en m'écrivant du russe ou de l'allemand, car j'aime mieux avoir dans mes villes de bons gros bourgeois et riches marchands que des petits-maîtres. Je crains qu'avec le langage ils ne changent de moeurs." See Catherine's draft of a letter to the Field Marshal Münich, written on February 9, 1766, in Sbornik Russkogo Istoricheskogo Obshchestva [SRIO] 10 (1872): 66.

${ }^{20}$ For a discussion of the two types, see Claude Adrian Helvétius, Oeuvres philosophiques de M. Helvétius (London: [s. n.], 1791), 3: 141-52, 207-208. On the critical attitude to fops, see, for example, Rogger, National Consciousness in Eighteenth-Century Russia, 43-44, 48-84. For a discussion of analogies between Catherine's criticism of luxury at Elizabeth's court in her memoirs and such criticism in Fénelon's Les Aventures des Telémaque, see Vacheva, Romanut na Imperatrisata, 127.
} 
and daily routine. ${ }^{21}$ Whereas Elizabeth's court came to be associated with changing fashions and an emerging commercial culture, with the empress herself indulging in luxury and sartorial extravagance, Catherine II put an emphasis on the collection and preservation of cultural artifacts, understood as a way of increasing the wealth of her empire, rather than spending it. To Voltaire's surprise, she continued to amass European art in the middle of the Russo-Turkish war (17681774) after losing 6o,ooo works in the Baltic Sea. ${ }^{22}$ In her letter to Madame Geoffrin, she mentioned that she wanted to be remembered as a collector rather than a consumer. ${ }^{23}$

The nature of the spaces allocated to a woman of fashion and a woman of sense in eighteenth-century cultural imagination further highlighted the difference in occupations and qualities of the two cultural types. The symbolic space of a woman of fashion being the boudoir, Catherine preferred to present her own space as a private office (cabinet), previously associated with male culture. In her memoirs, with reference to her life during the last years of Elizabeth's reign, Catherine II called the secret room that she made in her bedchamber a "cabinet," adding military-like defensive features to the space surrounding it: "there was a side door leading into a kind of wardrobe (...) which was quite barricaded with screens and chests." ${ }^{24}$ As Angelina Vacheva has suggested, the empress described this personal space as a bastion of military actions and political resistance where she could exercise her power and initiative. ${ }^{25}$ The need to stress the fact that the empress's office was no boudoir, but a place of intellectual work worthy of an enlightened monarch, is evident also in the letter written by Prince Charles-Joseph de Ligne (1735-1814) to Catherine II on May 8, 1793:

"The Petersburg cabinet has been notable for two qualities [nobleness and justice] for thirty years. It is the smallest of all the cabinets known to me: it is only of several inches in height and width, from the brows to the crown

\footnotetext{
${ }^{21}$ See Catherine's letter to Madame Geoffrin of November 6, 1764, in SRIO 1 (1867): 261. See also Voltaire's laudatory remark to the empress about truth coming from the north and playthings coming from the south in his letter of July 24,1765 , as well as his compliments to the hard-working empress in his letter of January 24, 1777, in William F. Reddaway, ed., Documents of Catherine the Great: The Correspondence with Voltaire and the Instruction of 1767 in the English text of 1768 (Cambridge: Cambridge UP, 1931), 3, 210; Grigorovich, "Kantsler kniaz' Bezborodko," in Petr Bartenev, ed., Russkii arkhiv 15.1 (1877): 23; E. A. Kharitonova, "Zapiski fel'dmarshala Minikha," Russkaia starina 9.1 (1874): 105.

${ }^{22}$ On Catherine's collecting activities, see her notes to Ivan Elagin in SRIO 10: 184. See also Voltaire's letter to Catherine II of January 14, 1772 in Reddaway, ed., Documents of Catherine the Great, 150-51.

${ }^{23}$ SRIO 1: 275.

24 "il y avait une porte de dégagement qui donnoit dans une espèce de garderobe (...) qui étoit très barricadée d'ecrans et de coffres." Catherine II, Sochineniia imperatritsy Ekateriny II, 12: 402.

${ }^{25}$ Vacheva, Romanut na Imperatrisata, 196-97.
} 
and from one temple to the other. This cabinet is not a boudoir, as the work carried out there always bears a stamp of a lucid mind." 26

Prince de Ligne eliminated all gendered characteristics from his description of Catherine's office. Yet, by seeking to dispel potential associations of Catherine's cabinet with a boudoir, probably in response to opponents who continued to question Catherine's authority, he nonetheless actualized the latent cultural stereotype. Moreover, his assessment of the empress's qualities evidently relied on the image cultivated by the empress herself. By demonstrating the importance of labor and duty in her life, the value of reason, utility, and frugality--conveyed, among other things, through the scarcity of her wardrobe as compared to that of Elizabeth--Catherine II emphasized her desire to be perceived as a woman of merit and an enlightened monarch, as well as her preference for stability and tradition over Elizabeth's penchant for foppish change and leisure. ${ }^{27}$

\section{Catherine II as Matriarch and Craftswoman}

One of the most significant and popular models of cultural behavior on which the empress relied to cultivate a favorable attitude to her womanhood was that of a matriarch. Russian society responded favorably to matriarchal rhetoric, as maternal authority did not undermine traditional social hierarchies. This familial language of communication between a sovereign and his subjects was, to some extend, shaped by biblical rhetoric. Furthermore, the importance of common interests between an enlightened monarch and his people, where a sovereign would take care of the public weal, and the populace would support his policies, was one of the principles of the Enlightenment promoted by Catherine II at the level of state ideology. The empress's views on governance were, to some extent, shaped by her reading and translation of Jean-François Marmontel's Bélisaire [Belisarius] during her Volga trip in 1767. Marmontel argued for the necessity of establishing a paternal form of power ("pouvoir paternal") with the monarch assuming the role of patriarch ("chef d'une famille") in relation to his populace. ${ }^{28}$ The empress gave semblance to the realization of these principles shaped by both traditional and Enlightenment discourse when she convened the Legislative Commission (1767-1768). ${ }^{29}$ The translation of Belisarius, which she undertook with

\footnotetext{
${ }^{27}$ On Catherine's preference of old rules, see her letter to Baron von Grimm of April 23, 1791, in Bartenev, ed., Russkii arkhiv 16:3 (1878): 182; and Catherine II, Sochineniia imperatritsy Ekateriny II, 12: 211, 301-302, 329-30, 352. See also Voltaire's teasing juxtaposition of "a victorious and law-making Empress" to a fickle French coquette in his letter to Catherine II of August 9, 1774, in which he playfully complained about falling into disgrace at Catherine's court. His complaint was caused by the interruption in their correspondence. Reddaway, ed., Documents of Catherine the Great, 198.

${ }^{28}$ Marmontel, Bélisaire, 70-72, 85-90, 117-30, 169-71.

${ }^{29}$ For a discussion of the impact of Bélisaire on Catherine's views about governance, see Ivinskii, Literaturnaia politika Ekateriny II, 12-14.
} 
her court circle during the Volga trip, became one of her first educational projects involving the Russian political elite.

In her manifestoes, the empress promoted a self-image of a benevolent matriarch deeply concerned with the public weal, and used familial language to construct her relationships with her subjects. She repeatedly compared her concern for her subjects with that of a loving mother endowed with divine grace. An excerpt from the draft of her speech composed for the members of the Legislative Commission provides a fine illustration of this approach:

"Her Imperial Highness's maternal heart, which is so fond of her people, was very pleased to see how heartily her command was taken by every kind of person, and one might say, all spirits united to contribute with their ideas to that great undertaking for which they were told to dispatch you to this ancient capital. The above mentioned famous manifesto already states on behalf of her Imperial Highness that her desire is to see her people as fully happy and contented as human happiness and contentment can ever expand on the earth. These words have served as a guiding principle for her Imperial Highness in all her enterprises from the day of her accession to the present day. All her divinely blessed accomplishments can be attributed to the very same words that incited that trust and filial love for her person. These sentiments can be easily noticed in every subject who stands here, but become even clearer from the compositions of many of your instructions." 30

The empress further reinforced this maternal connection with her subjects in her positive response to the decision of the Legislative Commission to bestow the title of a "Great and Wise Mother of the Fatherland" upon her. ${ }^{31}$ This conferment had precedent in early eighteenth-century history when the titles of "Emperor" and

\footnotetext{
30 "Ея Императорскаго Величества матернему, нежному к своему народу сердиу весьма приятно было видеть, с каким усердием принято сие ея повеление во всяком роде людей, и, так сказать, все духи соединились в том, чтоб своими представлениями споспешествовать великому тому делу, для котораго им велено прислать вас в сию древнюю столицу. Со стороны Ея Императорскаго Величества в выше названном том достопамятном манифесте сказано уже, что ея желание есть видеть свой народ столь счастливым и довольным, сколь человеческое счастие и довольствие простираться может на сей земле, -слова, кои Ея Императорскому Величеству от дня восшествия ея до сего дня во всех ея предприятиях правилом служили, коим, под благословением Божеским, и все ея успехи приписать можно и кои возбудили ту доверенность и детскую любовь к ея особе, кои не токмо во всяком из здесь ныне предстоящих легко приметить можно, но наипаче ясно оказываются из составов многих ваших наказов." See SRIO 10: 235. I preserved most peculiarities of eighteenth century orthography in the originals. See also Catherine's manifestos directed against revolts in "Vozmutitel'nye vozzvaniia," Bartenev, ed., Russkii arkhiv 16:3: 371-72. On Catherine's goals with regard to her subjects, see her manifesto of December 1766, as quoted in $S_{\text {SRIO }} 4$ (1869): 38-39; and her letter to Madame Geoffrin of January 15, 1766, in SRIO 1: 283.

${ }^{31}$ According to Bil'basov, Istoriia Ekateriny Vtoroi, 284, this offer has been made to the empress with her concurrence.
} 
"Father of the Fatherland" were bestowed upon Peter I in 1721. The analogy helped the empress to enhance her symbolic capital. While responding to the Commission's request, she expressed her reservations about the first two attributes conferred on her, and chose to focus on her maternal role. Starting her response in the third person, she shifted to a more intimate first person when she referred to the title.

"As for the titles that you wish me to accept, I respond to your offer in the following way: 1) regarding the attribute "the Great" - I leave it to time and posterity to judge my deeds impartially. 2) As for "the Wise" - I cannot call myself such, as only God is wise; and 3) as for the attribute-"Mother of the Fatherland," - I consider it a duty conferred upon me by my title to love my God-given subjects, and it is my wish to be loved by them." ${ }^{32}$

In both examples, the secular perception of a sovereign as the guardian and protector of the public weal was combined with religious overtones. ${ }^{33}$ By highlighting her royal predestination and benevolent reciprocity in her relationships with her subjects, the empress established the basis for a positive assessment of her authority. At the same time, her mothering language appealed to emotion. It helped the empress to nurture a sense of community and establish durable affective bonds with her subjects. ${ }^{34}$ The image of a caring mother outlived the empress, as the subjects continued to evoke it after her death. ${ }^{35}$

\footnotetext{
32 “О званиях же, кои вы желаете, чтоб я от вас приняла: на сие ответствую 1) на Великая, -о моих делах оставляю времени и потомкам безпристрастно судить. 2) Премудрая, -- никак себя таковою назвать не могу, ибо один Бог премудр, и з) Матери Отечества, -- любить Богом врученных мне подданных я за долг звания моего почитаю, быть любимою от них есть мое желание." See SRIO 4: 65. See also discussions of the title by members of the Legislative Commission in $\mathrm{SRIO}_{4}$ : 61-64.

${ }^{33}$ For a discussion of the convergence in Russian state ideology of messianism and European views on absolute monarchy, see Viktor M. Zhivov, "The Myth of the State in the Age of Enlightenment and Its Destruction in Late Eighteenth-Century Russia," Russian Studies in History 48:3 (20092010), 15-19.

${ }^{34}$ In order to establish her social and political genealogy, the empress underscored familial bonds with Peter I, Catherine I, and Elizabeth in her letters and state documents. She employed familial language in reference to her predecessors more frequently than Elizabeth, Paul or Alexander I did. See Catherine II, "Manifesty po povodu vosshestviia na prestol imperatritsy Ekateriny II," in M. Lavrinovich \& A. Liberman, comps., Ekaterina: Put' k vlasti (Moscow: Fond Sergeiia Dubova, 2003), 273-75; an instruction given to Count Petr Rumiantsev on his appointment as a General-Governor of Little Russia in SRIO 7 (1871): 383; Catherine's decree to the Senate of March 22, 1765, in Petr I. Bartenev, ed., Arkhiv kniazia Vorontsova (Moscow: [s. n.], 1875), 7: 641; the empress's letter to Count Mikhail Vorontsov of December 2, 1764 in Bartenev, ed., Arkhiv kniazia Vorontsova, 650.

${ }^{35}$ See, for example, Count Mikhail Vorontsov's letter to Catherine II of September 23, 1765, in SRIO 9 (1872): 76; a folk poem about Catherine II, and Vasilii Bil'basov's comments about the empress's popularity among common people, in Bil'basov, "Pamiati Imperatritsy Ekateriny II," in Sergei N. Iskiul', comp., Ekaterina II: Pro et Contra: Antologiia (St. Petersburg: izdatel'stvo Russkoi khristianskoi gumanitarnoi akademii, 2006), 902. See also F. A. Bühler's comments in "Dva episoda iz tsarstvovaniia Ekateriny II," in Iskiul', comp., Ekaterina II, 839, and Prince Bezborodko's reaction
} 
This mothering discourse was further developed in a more playful manner in the periodical Vsiakaia vsiachina [All Sorts of Things] (1769-1770), where Catherine II as initiator of the journal and its key contributor assumed the matriarchal role of "great grandmother All Sorts of Things." ${ }^{36}$ On the one hand, this particular modification of a maternal identity allowed the empress to distance herself from her unsuccessful real mother-son relationship, and, on the other, to add into her narrative the role of "elder." In this journal, the empress continued the tradition of European periodicals like The Tatler (1709-1711), The Spectator (17111712) and The Guardian (1713), ${ }^{37}$ and initiated a discussion of the role of customs, morality, and education in society. According to Viktor Zhivov, the journal with its secular moralism helped to shift the focus from necessary political reforms to a discourse of education and upbringing aimed at developing a society suitable for these reforms. ${ }^{38}$ Morality and education were already established safe topics of Russian didactic literature that gave the power of authority to their proponents. Thus, the empress set up and mediated a forum for her subjects where they were encouraged to engage in discussions of safe cultural topics. ${ }^{39}$ In addition, the periodical offered socially approved models of cultural behavior in polite society..$^{40}$

When the empress decided to become a writer to promote her authority and explain her views on society and culture, she modeled her behavior on that of enlightened monarchs. Yet she also transgressed onto the public domain

to Catherine's death in Nikolai Grigorovich, “Kantsler kniaz' Bezborodko," in Bartenev, ed., Russkii arkhiv 15.1 (1877): 50.

${ }^{36}$ Although the empress did not advertise her role in the journal, writers were aware of her involvement. On the extent of her involvement, see N. P. Avtonomov, "Vsiakaia vsiachina." (Satiriko-nravouchitel'nyi zhurnal 1769-1770 g). Opyt issledovaniia (Moscow: [s. n.], 1913), 67-73.

${ }^{37}$ Vsiakaia vsiachina 19 (1769): 53. According to Aleksei N. Veselovskii, the first reference to The Spectator in Russian publications goes back to 1725. See Veselovskii, Zapadnoe vliianie $v$ novoi russkoi literature (Moscow: tipolitografiia tovarishchestva I. N. Kushnerev i ko., 1916), 87. On the publication of translations from The Spectator, see V. Solntsev, "Vsiakaia vsiachina" $i$ "Spectator." (K istorii russkoi satiricheskoi zhurnalistiki XVIII veka (St. Petersburg: Tipografiia V. S. Balasheva, 1892), 6-8; Avtonomov, "Vsiakaia vsiachina," 19. On genre and thematic similarities between European and Russian eighteenth-century periodicals, see Ioachim Klein, "Nemedlennoe iskorenenie vsekh porokov": o moralisticheskikh zhurnalakh Ekateriny II i N. I. Novikova," in XVIII vek 24 (St. Petersburg: Nauka, 2006), 153-65.

${ }^{38}$ Viktor Zhivov, "Vsiakaia vsiachina' i sozdanie Ekaterininskogo politicheskogo diskursa," in Roger Bartlett \& Gabriela Lehmann-Carli, eds., Eighteenth-Century Russia: Society, Culture, Economy (Berlin: Lit Verlag, 2008), 252-53. For a further discussion of the discrepancy between the state ideology and the mechanism of state government, see Zhivov, "The Myth of the State," 10-29.

39 The writing of dramatic works, in which education was one of the central topics, was another important Enlightenment-inspired project for the empress. For an assessment of the cultural importance of Catherine's plays, and of thematic links between her periodical and her plays, see Evstratov, "Ekaterina II i russkaia pridvornaia dramaturgiia," 141-204.

${ }^{40}$ For a discussion of All Sorts of Things' educational goals, see Ivinskii, Literaturnaia politika Ekateriny II, 15-21. For Catherine's conception of an ideal citizen, see her Book on the Duties of Man and Citizen (1783), in Joseph L. Black, Citizens for the Fatherland: Education, Educators, and Pedagogical Ideals in Eighteenth-Century Russia (Boulder: East European quarterly, New York, 1979), 216-27, 241-59. 
traditionally associated with male authority. In the eighteenth century, noblewomen engaged in private epistolary correspondence. According to Dena Goodman, the process gave them a sense of autonomy and self-realization, but writing as a form of political and social involvement was not a common women's occupation. ${ }^{41}$ In Nikolai Novikov's journals (1769-1774), public writing was presented as a male occupation and compared with fighting, with sword and pen having interchangeable meanings. Moreover, a literary vocation was often considered an artisan's job unsuitable for a nobleman. The distance between a noblewoman and a woman writer was even more substantial.

In the Russian context, Catherine II was the first empress to engage actively in public writing. To secure her role as a patron of literature, a respectable educator, and a promoter of her own cultural policies, she resorted to fashioning her identity in the matriarchal garb of a great-grandmother. She chose this guise to gain her readers' respect and the right to pronounce words of wisdom. Significantly, though, she thereby also challenged the existing metaphor of patriarchal authority/authorship by offering an alternative conception of "mothering" or "great-grand-mothering." Entering the domain of public writing, and choosing the field of political and didactic writing practiced by enlightened monarchs, Catherine II nonetheless exercised a different approach to literary resources than male authors did. First, she made a compromise with a conventional perception of women's cultural roles by resorting to epistolary genres practiced by both genders. Second, she assumed the domestic role of a greatgrandmother when writing for periodicals. ${ }^{42}$ (In reality, she took on multiple identities composing texts under male and female pseudonyms). Third, she emphasized her role of educator involved in the upbringing of her subjects; and finally, she launched an attack on fops to distance herself from any associations with male or female weaknesses.

Furthermore, in the periodical, she continuously reinforced her sense of belonging to Russian culture, for example, by employing Russian proverbs in her responses to the readers. ${ }^{43}$ Rhetorically, the use of proverbs made it difficult for her opponents to argue with her opinions, which were clothed in undisputable words of wisdom. Later on, in the primer compiled for her grandsons in 1782, the

\footnotetext{
${ }^{41}$ Dena Goodman, Becoming a Woman in the Age of Letters (Ithaca \& London: Cornell UP, 2009), 13. For a discussion of writing as a male occupation and of genres associated with masculine and feminine terrains, see Goodman, Becoming a Woman, 8-10, 49, 65. See also Carla Hesse, The Other Enlightenment. How French Women Became Modern (Princeton and Oxford: Princeton UP, 2001), 43-55. Hesse challenged the perception of French women writers as being socially marginal and discussed their involvement in political writing during the revolution.

${ }^{42}$ As Kevin J. McKenna has suggested, "her grandmotherly status automatically placed her in a role of authority" ("Empress Behind the Mask: The 'Persona' of Md. Vsiakaia Vsiachina in Catherine the Great's Periodical Essays on Morals and Manners," Neophilologus 74.1 (1990), 3). Catherine's first journal Vsiakaia vsiachina was succeeded by Baryshek vsiakoi vsiachiny [Return on All Sorts of Things] (1770).

${ }^{43}$ On Catherine's policies concerning theater that encouraged a reflection of cultural specificity in dramatic works, see Evstratov, "Ekaterina II i russkaia pridvornaia dramaturgiia" 93-107, 139.
} 
empress underlined a strong affinity between the maxims and ideas communicated in her educational and legislative documents. In the first section of the primer, entitled "Elementary Civic Education," the empress included a selection of aphorisms, some of which, as she stated in the footnote, were taken from her Great Instruction to the Legislative Commission (1767) ${ }^{44}$ In a footnote to the second section, which also contained a selection of proverbs, she highlighted that they could support or clarify ideas developed in the first part of her primer and in The Great Instruction, thereby asserting that her documents were rooted in a recognizable cultural vocabulary. ${ }^{45}$ The simple language of maxims had the additional pedagogical function of making the language of her policies more accessible.

The proverbs presented a model of social relations based on shared values of trust, reciprocity, and humaneness, which the empress advocated for in a number of documents. Thus, one of the proverbs attempted to deflate prejudices against the poor: "Хотя шуба овечья, да душа человечья" [lit.: Although his coat is made of sheep's fur, his soul is human]; while another emphasized economic dependence of an owner on his peasant: "Не будет пахатника, не будет $u$ бархатника" [lit.: No plowman, no velvet-wearer]. ${ }^{46}$ Montesquieu's ideas about a strong attachment of common people to established laws and customs most probably influenced Catherine's decision to appeal to maxims. ${ }^{47}$ The proverbial language as a rhetorical tradition was also linked with the culture of elders and the cultural transfer of wisdom from older to younger generations, with women often playing leading roles in this transfer. Thus, Catherine's wide employment of maxims in her pedagogical and literary works further contributed to her construction of a matriarchal identity.

Finally, the empress demonstrated her fulfillment of a traditional, domestic role through her engagement in textile handicrafts. This type of occupation was expected from a good mistress of a household, as conveyed in The Domostroi ${ }^{48}$ and as Ivan Zabelin showed in the data on the life of sixteenth- and seventeenth-

\footnotetext{
${ }^{44}$ See Catherine II, Izbrannye sochineniia (St. Petersburg: Tipografiia Glazunova, 1894; Charlestown: Acme Bookbinding, 2004), 1.

${ }^{45}$ Catherine II, Izbrannye sochineniia, 20.

${ }^{46}$ Catherine II, Izbrannye sochineniia, 22, 24.

${ }^{47}$ See Charles de Secondat, Baron de Montesquieu, De l'esprit des lois (1748), (London: [s. n.], 1768), 1: 83. On Catherine's appeal to axioms in her policies, see drafts of her letters to D'Alembert and Voltaire written in 1765, in SRIO 10: 29-30, 35. In her letter to D'Alembert, SRIO 10: 30, the empress emphasized the importance of indisputable principles based on axioms in her policies when she reproached Jesuits for choosing ground rules that were not based on truth, and therefore were easily refutable.

${ }^{48}$ Carolyn Johnston Pouncy, ed. \& trans., The Domostroi: Rules for Russian Households in the Time of Ivan the Terrible (Ithaca \& London: Cornell UP, 1994), 95, 102, 126-27, 181. Pouncy suggests that the rules of The Domostroi still dictated modes of behavior of a conservative part of society (e.g. provincial gentry and merchants) in the eighteenth century (Pouncy, ed. \& trans., The Domostroi, 46).
} 
century Russian tsarinas. ${ }^{49}$ The burgher ideal of domestic life incorporated a similar set of values. Memoirs and documents of the period recounted Catherine's habit of knitting and embroidering. For example, Gavriil Derzhavin recorded that the empress engaged in knitting stockings and lace-knitting while listening to her courtiers' reports. She also referred to her textile occupations in communication with public figures. Besides contributing to the construction of a domestic selfimage, such references inspired positive analogies with the artisan emperor Peter I.

Yet the empress went further and employed textile and garment metaphors to reverse the conventional perception of women as suited mainly for domestic life, and to show that a woman was capable of being a good sovereign. In her personal correspondence, conversations with her subjects, as well as published literary pieces, the empress compared political plotting and writing with knitting. While conversing with Derzhavin on one occasion, she used a knitting metaphor to refer to her policies regarding France: "Who if not I enabled Frenchmen to understand the right of man? Now I am tying little knots, let the Frenchmen untie them." ${ }^{\circ}$ An implied allusion here is to the difficulty of untangling the Gordian knot. The empress compared her own actions with the cutting of the Gordian knot in her letters to Baron F. M. von Grimm written on November 17, 1782 and on April 20, $1783 .{ }^{51}$ Likewise, describing her progress on The Great Instruction in the letter to Madame Geoffrin on April 6, 1766, Catherine II placed sewing and writing side by side, making an analogy between the two activities: "My major work is moving along just as is my embroidering; the former-during two hours in the morning; the latter-during reading time after lunch." ${ }^{52}$

Furthermore, the empress employed textile and clothing metaphors to illustrate challenges arising from the implementation of new cultural policies. Clothing metaphors were a part of the biblical rhetorical tradition. Their wide employment in eighteenth-century Russian discourse originated from Peter's promotion of a symbolic covenant with his subjects through dress reforms that aimed at publicizing and domesticating his new, "westernized" social order. Thus,

\footnotetext{
${ }^{49}$ For a discussion of handicrafts in the life of sixteenth- and seventeenth-century noblewomen, see Ivan Zabelin, Domashnii byt russkikh tsarei v XVI i XVII stoletiiakh, 2 vols. (Moscow: Iazyki russkoi kul'tury, 2000), 1.1: 249; Domashnii byt russkikh tsarits v XVI i XVII stoletiiakh, 2 vols. (Moscow: Iazyki russkoi kul'tury, 2001), 2: 276, 285, 361, 367, 531, 544-59.

50 "Кто дал, как не я, почувствовать Французам право человека? Я теперь вяжу узелки, пусть uх развяжут." See Gavriil Derzhavin, Sochineniia Derzhavina s ob"iasnitel'nymi primechaniiami Ia. Grota (St. Petersburg: izdatel'stvo Imperatorskoi Akademii nauk, 1871), 6: 632.

${ }^{51}$ Bartenev, ed., Russkii arkhiv 16.3 (1878): 82, 90. For a discussion of the empress's habit of embroidering, see Mikhail I. Pyliaev, Staryi Peterburg, $2^{\text {nd }}$ ed. (Moscow: IKPA, 1990; St. Petersburg: Tipografiia A. S. Suvorina, 1889), 189. On Catherine's needlework, also see her letter to Madame Bielcke of September 9, 1767, in SRIO 10: 238-39; the empress's letter to Friedrich Melchior, Baron von Grimm of May 16, 1778, in Bartenev, ed., Russkii arkhiv 16.3 (1878): 48; and Baron von Grimm, "Istoricheskaia zapiska o proiskhozhdenii i posledstviiakh moei predannosti imperatritse Ekaterine II, do konchiny eia velichestva," in SRIO 2 (1868): 329.

52 "Моя большая работа подвигается, равно как и мое шитье; первая в продолжении двух часов утром, второе во время чтения после обеда." SRIO 1: 288.
} 
in issue No. 62 of All Sorts of Things, Catherine II employed an image of the caftan, which was linked with the Petrine dress reforms and was frequently employed in eighteenth-century discourse to comment on Russian political and cultural tendencies. She used it to illustrate the ineffective work of the Legislative Commission, which was expected to put her Great Instruction into practice:

"The tailors began arguing about the cut, while the peasant shivered in the yard (...). One said: our master wishes to see German caftans on his peasants. The other: we were told to sew a caftan, but we were not given instructions about the sleeves. The third said that one could not cut out a caftan without seeing the buttons. The fourth mentioned that a half of the cloth was not enough for such a fat peasant; two halves were necessary. Finally they started to cut wider anyhow waiting for the butler to settle the argument. Four boys came (...). The butler ordered them to help the tailors right away. These boys knew how to read and write, but were very bold and impudent: they started to shout and make a row." ${ }^{53}$

This tailoring parable most probably alludes to contemporary discussions about serfdom, which sparked much controversy among the members of the Commission. The gist of the parable is that legislative plans fail when social groups defend their exclusive interests, and thus are unable to come to terms with each other. ${ }^{54}$

Issue No. 77 of All Sorts of Things employed similar garment metaphors to express concerns about the appropriateness of Peter's radical reforms:

“(...) when I was young, I preferred Russian dress because it seemed to agree with prudence more than French clothing. They told me that I had a savage taste. Now I praise this dress because it seems more fitting for our climate than any other clothing." 55

\footnotetext{
53“Портные стали спорить о покрое, а мужик между тем на дворе дрожит (...). Иный говорит: хозяин наш желает видеть на своих мужиках кафтаны Немецкие. Другий: нам велено шить кафтан; а о рукавах мы приказания не имеем. Третий сказал: что не видав, какия будут пуговицы, не льзя кроить. Четвертый молвил, что такому толстому мужику половинки сукна мало; надобно две. Наконец кое как зачали кроити в запас, пока дворецкий разрешит спор. Вошли четыре мальчика (...). Дворецкий приказал им тут же помогать портным. Сии мальчики умели грамоте, но были весьма дерзки и нахальны: зачали кричать и шуметь." Vsiakaia vsiachina 62 (1769): 166.

${ }^{54}$ See interpretations of Catherine's image of the caftan in Pavel N. Berkov, Istoriia russkoi zhurnalistiki XVIII veka (Moscow \& Leningrad: Akademiia nauk SSSR, 1952), 174-75; Olga B. Lebedeva, Istoriia russkoi literatury XVIII veka (Moscow: Akademiia, 200o), 177. Denis Fonivizin in The Minor (1782) and Ivan Krylov in "Trishka's Caftan" (1815) employed similar garment metaphors to provide critical illustrations of management failures on personal and domestic levels.

55 “(...) в юности моей предпочитал я Руское платье для того, что оно мне казалося сходнее со благоразумием, нежели Французкое. Мне говорили на то, что я дикий вкус имею. Теперь я его хвалю за то; мне кажется оно всякаго платья приличнее к нашему климату." Vsiakaia
} 
At the end of this piece, a compromise was made between Russian and French garments in favor of cultural hybridization: if one cuts off excessive parts from the Russian dress and adds missing parts to the French "caftan," the product of these alterations will agree with both climate and common sense. ${ }^{56}$ Viktor Zhivov interpreted the image of the garment that underwent tailoring as a metaphor for Catherine's program of reforms, which she carefully set in opposition to Peter's policies. Advocating her course of action over that of Peter I, the empress followed the French Enlightenment paradigm. She relied on sound judgment and took into consideration her country's specificities. ${ }^{57}$ Montesquieu advocated for the same principle of moderation in government practices in The Spirit of Laws. ${ }^{58}$ In general, the empress employed a different method than Peter I in popularizing her policies, often "clothing" her ideas, even those that had a reformist nature, in traditional "garments." This approach, which aimed at cultural reciprocity, added a softer, more enlightened touch to the implementation of her policies.

It was not uncommon for male writers to employ similar textile and sartorial metaphors in their communication with the empress. However, the fact that she nurtured a favorable attitude to her femininity through references to

vsiachina 77 (1769): 201. The author drew on Montesquieu's idea about the influence of climate on the formation of society and its form of government. See Montesquieu, De l'esprit des lois, 2: 189.

${ }^{56}$ Vsiakaia vsiachina 77 (1769): 201-203. See Nikolai N. Bulich, Sumarokov i sovremennaia emu kritika (St. Petersburg: Tipografiia Eduarda Pratsa, 1854), 220, 229, for a discussion of the analogy between this reconciliatory sartorial image and a similar tone adopted by the periodical. On similar comparisons of statecraft with tailoring and shoemaking crafts, see Catherine's letter to Voltaire of May 29/ June 9, 1767:

"Me voilà en Asie; j'ai voulu voir cela par mes yeux. Il y a dans cette ville vingt peuples divers, qui ne se ressemblent point du tout. Il faut pourtant leur faire un habit qui leur soit propre à tous. Ils peuvent se bien trouver des principes généraux; mais les détails? Et quels détails! J'allais dire: C'est presque un monde à créer, à unir, à conserver. Je ne finirais pas, et en voilà beaucoup trop de toutes façons."

[Here I am in Asia; I wanted to see it for myself. There are in this city twenty different people, who bear absolutely no resemblance to each other. However, I have to make them a suit which will fit them all. It is not hard to find general principles; but what about the details? And what details! I might say there is almost a whole world to be created, united, preserved. I may never be able to complete it; there are far too many different customs here].

Reddaway, ed., Documents of Catherine the Great, 18; Lentin, ed. \& trans., Voltaire and Catherine the Great, 48. See also Catherine's allusion to her legislative project through the image of a tight boot that needs some adjustments, in her address to the members of the Legislative Commission. Bil'basov, "Pamiati Imperatritsy Ekateriny II," 870-71.

${ }^{57}$ See Zhivov, "Vsiakaia vsiachina' i sozdanie Ekaterininskogo politicheskogo diskursa," 257.

${ }^{58}$ Montesquieu, De l'esprit des lois, 1: 44-46, 102-103, 128, 2: 208-209, 3: 127. Marmontel also advocated for moderation. See Bélisaire, 109, 156, 169. Both in her letters and instructions to her subjects, Catherine II emphasized the importance of moderation. See SRIO 1: 134; SRIO 9 (1872): 150. 
traditional domestic tasks added a gender-conscious coloring to the dialogue between the empress and the writers. Hence, Nikolai Novikov and other authors wittily undermined her authority through allusions to domestic chores. In issue No. 8 of Truten' [The Drone] (1769-1770), one of the contributors employed the verb "otpriast'," the root of which derives from the verb priast' [to spin], to refer to royal criticism of the periodical: "его ['Трутень'] недавно отпряла Всякая всячина очень хорошо" ([Mme] All-Sorts-of-Things recently rebuffed him [The Drone] quite well). ${ }^{59}$ In the context of the letter, the verb otpriala implies that Mme All-Sorts-of-Things urged Mr. Drone not to forget his position and to watch his tongue.

When Catherine II chose the role of "great-grandmother All-Sorts-ofThings" for her communication in the periodicals (1769-1774), she wished to strike a balance between patronizing and apologetic tones, as a way of creating a more inclusive and accepting debating environment. This identity enabled the empress to command respect for her authority, and simultaneously to cast a sympathetic eye on her own and her subjects' weaknesses, as old age had implications not only of virtue, wisdom and authority, but also of declining faculties and preoccupation with petty things, nitpicking, as well as knitting. ${ }^{60}$ In this instance, however, Catherine's choice of familial relationships, did not work in her favor, since it allowed writers to violate her royal immunity. She made herself further susceptible to becoming the target of the writers' criticism by exposing her vulnerable feminine side.

Despite the assumed guise of a wise matron, she was at the time still fairly young and wished to appear likable and please her audience. She wanted to reconcile disagreeing parties through compromise, and thus treated her readers as her offspring, showing leniency when reproving members of her imagined family for their follies. Afinogen Perochinov's letter, in which this fictional author promised to pursue the following principles, illustrates well Catherine's forgiving approach:

“1) Never to call weaknesses vice. 2) Be philanthropic in all matters. 3) Not to think that it is possible to find perfect people, and therefore 4) ask God to grant us the spirit of meekness and leniency."

\footnotetext{
${ }^{59}$ Berkov, Satiricheskie zhurnaly N. I. Novikova (Moscow \& Leningrad: Akademiia nauk SSSR, 1951), 71. Berkov believed that this piece had been written by Novikov. I was unable to preserve this textile metaphor in the translation.

${ }^{60}$ For a discussion of concepts associated with women's old age in contemporaneous Great Britain, see Devoney Looser, Women Writers and Old Age in Great Britain, 1750-1850 (Baltimore: Johns Hopkins UP, 2008), 3-14.

61 “1) Никогда не называть слабости пороком. 2) Хранить во всех случаях человеколюбие. 3) Не думать, чтоб людей совершенных найти можно было, и для того 4) Просить бога, чтоб нам дал дух кротости и снисхождения." Vsiakaia vsiachina 53 (1769): 142.
} 
Novikov and other authors writing for contemporary Russian periodicals interpreted these principles as an example of Catherine's conciliatory diplomacy, and engaged in a gendered power struggle with the empress. Exposing her concessive stance, they attacked her female weaknesses rather than those of a sovereign, and compared her political decisions with the tricks and intrigues of a woman. In the letter addressed to "Mme All-Sorts-of-Things" and published in the journal Adskaia pochta [Hell's Mail] (1769), Feodor Emin criticized the empress's politically adaptive behavior, comparing the actions of Mr. Dobrosovetov [Mr. Kind Advice], a fictional author in All Sorts of Things, with those of a coquette flirting with her audience:

"I see, Mr. Kind Advice, that you would like to please everyone with these moral teachings of yours, but believe me that time will come when you will become akin to an ugly face that inappropriately adorns itself with ceruse and rouge. Beware that nothing can be concealed from all-gnawing time. Someday it will guzzle your weak politics, too; when your political ceruse and rouge come off, then the genuine essence of your thoughts will become apparent to everyone.

I am mostly surprised by the fact that you-Mme All-Sorts-of-Things-take such advice." ${ }^{62}$

While this criticism was explicitly directed against a male fictional author, the implied target was the empress herself. It was clear to Catherine's contemporaries that "Mr. Kind Advice" promoted her ideas, and the image of the empress was instantly recognizable behind the references to the adopted pseudonym of Emin's actual addressee.

Some authors went further in their criticism of Catherine's desire to please her readers, constructing an image of an aging, careless coquette:

"It is time for you gentlemen, grandsons and nephews of an old woman, who is well-known in these parts, to ask your grandmother to observe better constancy in her leaflets proper for her old age; otherwise, she is

\footnotetext{
62 "Вижу, Добросоветов, что ты таким своим нравоучением всем нравиться хочешь, но поверь мне, что придет время, в которое будешь подобен безобразному лицу, белилами и румянами некстати украшивающемуся. Знай, что от всеснедающего времени ничто укрыться не может. Оно когда-нибудь пожрет и твою слабую политику, когда твои политические белила и румяна сойдут, тогда настоящее бытие твоих мыслей всем видным сделается.

Мне больше всего удивительно, что вы, госпожа Всякая Всячина, такие приемлете советы." L. B. Lechtblau, comp., Russkie satiricheskie zhurnaly XVIII veka (Moscow: Gos. uchebno-ped. izdatel'stvo Narkomprosa RSFSR, 1940), 151. The periodicals I to $i$ se [This and That] (1769) and Ni to ni se [Neither This nor That] (1769) excused weaknesses in Catherine's judgment and her grammatical mistakes by the old age of "Mme All-Sorts-of-Things." See Lechtblau, Russkie satiricheskie zhurnaly XVIII veka, 63-64, 68.
} 
fermenting like young beer to this day and cannot plant her thoughts on one foundation." ${ }^{63}$

The image of an aging coquette was not a historical construct based on the empress's age or her private life. It was based on Catherine's self-fashioning of her identity in the role of an old matriarch, and was possible due to the seeming anonymity of her mask. Her claims of familial ties with the periodicals, her tactic of compromise, and her desire to please her readers contributed to the writers' identification of Catherine II with an elderly flirt.

The character of an old coquette, which often coincided with the image of a woman of fashion, was common in European and Russian satirical literature, and its popularity indicated cultural anxieties about female sexual power. Fashion and coquetry were viewed as powerful instruments of manipulation and emancipation that attempted to unsettle patriarchy. They were often presented in a decaying form to diminish their potential harm. In addition, flirtation was an important part of inter-gender communication in polite society, while the type of a coquette was a surviving legacy of Elizabeth's court culture. In terms of gender politics, criticism of Catherine's grammar and style, and the gentlemanly condescension that Novikov displayed when he praised "Mme All-Sorts-of-Things" for her literary accomplishments, can be perceived as conventional claims of male authority over writing, and a well-conceived (and concealed) device of disarming satire. ${ }^{64}$ The polemic between the periodicals can be viewed through the tropes of concealment and exposure applied to the rhetorical goals of the corresponding parties. While the empress made playful attempts to validate her authority by basing it on the role of a matriarch, her opponents did their best to counter this move by using this same image to expose her female weaknesses, and the flaws and inconsistencies in her thoughts.

Catherine II continuously employed references to textile and sartorial activities to describe her cultural undertakings, among other things, making playful analogies between authorial and editorial tasks and a tailor's craft. In Byli i nebylitsy [Facts and Fancies], a column published in The Interlocutor of Lovers of the Russian Word (1783), she reinforced this comparison when she entrusted a

\footnotetext{
63 “Пора вам, господа внучата и племянники известной здесь старушки, попросить вашу бабушку, чтоб в листках своих получше наблюдала постоянство, старости ее лет приличное; а то она поныне как молодое пиво бродит и на одном основании мыслей своих остановить не может." This quotation appears in the periodical Smes' [Mixture] (1769), quoted by Lechtblau, Russkie satiricheskie zhurnaly XVIII veka, 76. On the analogous desanctification of Louis XV through references to his impotence, see Robert Darnton, The Forbidden Best-Sellers of Pre-Revolutionary France (New York \& London: W. W. Norton \& Co., 1995), 163-66, 212-13.

${ }^{64}$ For a discussion of conventions of male polite condescension towards women writers, see Susan Staves, A Literary History of Women's Writing in Britain, 1660-1789 (Cambridge: Cambridge UP, 2006), 20. As Olga Lebedeva suggested, one of Novikov's achievements in his discourse with Catherine II was to make her image private and domestic. The empress assisted the writer in the "domestication" of her image by making playful allusions to her roles of a grandmother and great grandmother in All Sorts of Things. See Lebedeva, Istoriia russkoi literatury XVIII veka, 171.
} 
fictional tailor with the publication of feuilletons. ${ }^{65} \mathrm{~A}$ lector who carried out most of the writing for the tailor followed the latter's sartorial advice on how to sew words tightly, so that they did not fall apart. While the lector filled the lines with the ideas taken from the books, the tailor mended a worn-out caftan. ${ }^{66}$ In the column, sartorial imagery helped the empress to convey her views on the language and narrative style she deemed appropriate for this work - the language which, on the one hand, had to be purified from foreign borrowings, and on the other hand, had to be simple, colloquial, and moderate in its usage, entertaining, and adaptable to cultural circumstances. ${ }^{67}$ This language, authored by the lector and the tailor, was thus a product of cultural hybridization-a product of Russian linguistic culture tailored in accordance with the French Enlightenment paradigm. Using textile and sartorial metaphors, the empress showed that her aim was to reform "outworn" ideas, to give them a new life in a changing cultural context. As she wished to attract more readers to her new periodical, she chose a craftsman, a person of low social standing, yet an artisan similar to Peter I, as a popularizer of her ideas in the column. Furthermore, by employing vocational vocabulary in reference to her royal tasks, and describing them as a "challenging craft/profession" (trudnoe $i$ tiazheloe remeslo), the empress reinforced the perception of statecraft as a professional occupation. ${ }^{68}$ This secular perception of state service, which Peter I popularized at the beginning of the century through his personal engagement in crafts and support of professional education and meritocracy, promoted political stability and encouraged what came to be perceived an Enlightened, Orthodox work ethic.

\section{The Household as a Model of the State and Catherine's Cultivation Projects}

Prior to the end of the seventeenth century, there was no tradition of female rule in Russia. Women who crossed into the political terrain were perceived as posing a challenge to the established hierarchy. ${ }^{69}$ In the family structure and

\footnotetext{
${ }^{65}$ Catherine II, Sochineniia Imperatritsy Ekateriny II, 5: 154-76.

${ }^{66}$ Catherine II, Sochineniia Imperatritsy Ekateriny II, 5: 156.

${ }^{67}$ For a detailed discussion of Catherine's language program, as formulated in The Interlocutor of Lovers of the Russian Word, see Ivinskii, Literaturnaia politika Ekateriny II, 86-92.

${ }^{68}$ See Catherine's letters to Madame Geoffrin, SRIO 1: 255-56, 258.

${ }^{69}$ The only female regents who reigned prior to the end of the seventeenth century were Princess Olga (945-962) and Elena Glinskaia (1533-1538). Before the reign of Catherine II, a political mythology based on the rhetoric of motherhood/grand-motherhood was not strongly pronounced, primarily because the women who were in power for a significant period of time-Sophia (r. 16821689) Anna Ioannovna (r. 1730-1740) and Elizabeth (r. 1741-1761) - did not fulfill their procreative roles. As Gary Marker has demonstrated, they relied instead on the cult of St. Catherine. For a discussion of the role played by this cult in the political mythology of Russian women in power, and the construction of their political identities around the images of a warrior-maiden and a holy maiden, see Gary Marker, Imperial Saint: The Cult of St. Catherine and the Dawn of Female Rule in Russia (DeKalb: Northern Illinois UP, 2007), 3-26, 54-74, 131-42, 217-23. For a discussion of life of
} 
household economy, however, women assumed both "superior and subordinate roles." ${ }^{70}$ As household mistresses, they gained a certain degree of authority, with their domestic role being elevated from that of a housewife to that of a house manager, and even a landowner in certain instances. ${ }^{71}$ Noblewomen acquired limited property rights during the Muscovite period, which were further expanded and protected in the eighteenth century. In 1730, they were granted more power over property. Thus, a widow was entitled to one-seventh of her deceased husband's immovable property and a quarter of his movable property. ${ }^{72}$ Dowries, which according to Elise Wirtschafter and Michelle Marrese, were becoming a part of a wife's personal property, gave women some economic independence. Women could purchase property, mortgage it in their names, become landowners, and even manage factories and other enterprises. ${ }^{73}$

Society looked favorably at women as household authorities, and Catherine II used the positive symbolic capital of this role to enhance her power at court, and among the representatives of political nation more broadly. The empress drew upon similarities between statecraft and housecraft and applied a traditional household model, familiar to all social estates, to the management of the Russian empire. Such modelling of state duties through the prism of housecraft can be, in part, explained by a tradition of regarding a family household as a miniscule model of the state; however, the analogy between housecraft and statecraft was also psychologically motivated. It decreased anxieties about a woman performing state tasks, psychologically helped the empress cope with her new responsibilities, and at the same time validated Catherine's new status and authority among both the elite and the general populace.

royal women and gradual changes in their lives, see Ivan Zabelin, Domashnii byt russkikh tsarits, 2 : 1-5, 82-101, 144-81, 286-93.

${ }^{70}$ Pouncy, ed. \& trans., The Domostroi, 27. On women's life before and after the Petrine reforms, see Natal'ia Pushkareva, Women in Russian History. From the Tenth to the Twentieth Century. Ed. \& trans. Eve Levin (Armonk \& London: M. E. Sharpe, 1997), particularly 61-185.

${ }^{71}$ According to Vladimir Mikhnevich, the roles of a housewife, a house manager, and a landowner were the most common for women in the eighteenth century. For a description of women's social roles in the eighteenth century, see Mikhnevich, Russkaia zhenshchina XVIII stoletiia (Kiev: F. A. Ioganson, [1895]), particularly 210-32.

${ }^{72}$ For a discussion of property and inheritance rights in seventeenth- and early eighteenth-century Russia, see Brenda Meehan-Waters, Autocracy and Aristocracy. The Russian Service Elite of 1730 (New Brunswick: Rutgers UP, c1982), 118-22.

${ }^{73}$ See Elise Kimerling Wirtschafter, Social Identity in Imperial Russia (DeKalb: Northern Illinois UP, 1997), 13; Michelle Lamarche Marrese, A Woman's Kingdom. Noblewomen and the Control of Property in Russia, 1700-1861 (Ithaca \& London: Cornell UP, c2002), 2, 21, 23, 26-27, 30-33, 46-52, 5456, 113-19, 123-38, 171-75, 191-97. Russian property laws were more liberal than the German laws at the time of Catherine's reign. The empress found it hard to believe that the German property left by her relatives became a subject of dispute instead of being passed directly to her as the closest family member. See Catherine's letter to Baron von Grimm of October 1, 1794, in Bartenev, ed., Russkii arkhiv 16.3 (Moscow, 1878): 215. In clauses 422-25 of her Great Instruction, the empress supported the distribution of inheritance between all heirs. See Reddaway, ed., Documents of Catherine the Great, 280-82. 
The empress utilized this domestic vocabulary in her memoirs, retrospectively referring to her life during Elizabeth's reign. Thus, she highlighted her expertise in handling her husband's and her own domestic, public, and even some state affairs. ${ }^{74}$ During her reign, Catherine used to call her empire a "small household" (malen'koe khoziaistvo). ${ }^{75}$ This playful diminutive analogy imparted a sense of ease and confidence to her handling of state affairs and tangentially reinforced familial bonds with her subjects. The empress made a similar analogy between the management of "a large family" (the state) and that of a private family in The Great Instruction, drawing on Montesquieu's perception of the small family as a microcosm of the large one. ${ }^{76}$ Catherine's references to her subjects' administrative duties and to the skills of European politicians were often phrased in similar domestic vocabulary. ${ }^{77}$

Within her "small household," Catherine's domestic and imperial roles interwove in her cultivation projects (the most obvious examples being gardening and education). In eighteenth-century culture, a garden was associated with both feminine and masculine roles, private and public spaces. The cultivation of gardens became an important domestic activity for the nobility, and was a popular occupation of enlightened sovereigns, with gardens symbolically representing and celebrating power and an idealized social order. For female sovereigns, cultivation of gardens had additional connotations. As gardens were associated with peaceful nature, harmony, and tranquility, they accentuated and celebrated these traditional virtues of female rulers. Catherine II started tending to her first garden at Oranienbaum in 1755 at the time when she was a grand duchess. In her memoirs, she retrospectively expressed her longing for self-sufficiency in reference to the acquisition and cultivation of the garden, ${ }^{78}$ and she viewed it as a place

\footnotetext{
${ }^{74}$ See, for example, Catherine's references to Elizabeth's and her own household management prior to their accessions, in Catherine II, Sochineniia imperatritsy Ekateriny II, 12: 210, 220-21, 303-304, 355-56, 372-78, 385, 398-99, 425-26.

${ }_{75}$ See Adrian M. Gribovskii, Zapiski o imperatritse Ekaterine Velikoi (Moscow: Universitetskaia tipografiia, 1864), 41; M. Filippov, “Tiur'my v Rossii," Russkaia starina 8 (1873): 62; "Kniaz' Grigorii Aleksandrovich Potemkin-Tavricheskii, 1739-1791 gg. Biograficheskii ocherk po neizdannym materialam," Russkaia starina 12 (1875): 696; Mikhnevich, Russkaia zhenshchina XVIII stoletiia, 213. See also Catherine's employment of the proverb "The eye of the master fattens the horse" in reference to her planned trip to Kazan in the letter to Madame Bielcke of August 26, 1766, in SRIO 9: 105-106.

${ }^{76}$ See Catherine II, Nakaz, clause 349, in Reddaway, ed., Documents of Catherine the Great, 271; Montesquieu, De l'esprit des lois, 1: 59.

${ }^{77}$ See, for example, an opening line in the first instructions to governors (1764): "The governor should be a master [...] in his province." SRIO 7:353. Also, see N. Koliupanov, "Ocherk vnutrennego upravleniia v Rossii pri Ekaterine II," in Iskiul', comp., Ekaterina II, 427-28; a report of the Legislative Commission on noblemen's rights and privileges composed by Grigorii Teplov and rewritten by Catherine II, in SRIO 7: 248; Count Petr Rumiantsev's report of May 18, 1765 about administrative problems, in SRIO 10: 16; Catherine's letters to Baron von Grimm of April 23, 1783 and April 21, 1791, in Bartenev, ed., Russkii arkhiv 16.3 (1878): 90, 179.

$7^{8}$ On Catherine's longing for self-sufficiency and autonomy expressed in reference to her landscaping plans, see Ekaterina II, Sochineniia imperatritsy Ekateriny II, 12: 355-56.
} 
where she could negotiate her autonomous space within the court. As Andreas Schönle has suggested, the garden became a place of retreat for the grand duchess from the stifling atmosphere of the court, and a semi-public space where she could create her own model of social relations. ${ }^{79}$ By the time the empress wrote about her first landscaping project in the memoirs, she was well acquainted with Voltaire's advice in Candide ou l'Optimisme [Candide or Optimism] (1759)_il faut cultiver notre jardin-and with the development of this gardening metaphor in Marmontel's Belisarius, where the art of landscaping was compared with that of governing. ${ }^{80}$ The fact that she retrospectively chose to present the gardener Lamberti's prediction about her becoming an empress in conjunction with the story about her first landscaping project signifies that she wanted the project to exemplify and justify her political ambitions.

The cultural construct of "the garden" represented the way Catherine II wanted to perceive her relationships with her subjects. The empress supported the concept of a natural garden, which manifested a synthesis of the agreeable and the useful. ${ }^{81}$ In the letter to Voltaire of June $25 / J u l y ~ 6,1772$, she expressed her penchant for natural lines:

"At the moment I have a passion for gardens in the English style: wavy lines, gentle slopes, ponds shaped like lakes, archipelagoes on dry land; and I hate fountains which force the water into unnatural shapes." ${ }^{82}$

The empress's fondness for natural elements reflected her initial inclination towards tolerance and plurality in her relationships with her subjects; while her engagement in landscaping reinforced the analogy between housecraft and statecraft. The shift from a sword to garden and sowing/sewing tools, and further to a pen, reflected the ideals of an enlightened monarchy, while Catherine's

\footnotetext{
${ }^{79}$ Andreas Schönle, The Ruler in the Garden: Politics and Landscape Design in Imperial Russia (Oxford \& New York: Peter Lang Pub Inc., 2007), 33, 40, 42-44, 48, 65, 75, 111.

${ }^{80}$ See, for example, the analogies between gardening and political economy in Marmontel, Bélisaire, 137, 139-140. "Un moment plus tôt, leur dit-il, vous auriez pris, comme moi, une bonne leçon dans l'art de gouverner: car rien ne ressemble tant au gouvernement des homes que celui des plantes, et mon jardinier que voilà en raisonne comme un Solon," 137. [Had you arrived, said he, a moment sooner, you would have learnt, as I myself have done, an excellent lesson in the art of governing; for nothing bears so strong a resemblance to political economy as the management of plants, and my gardener, who is here at hand, reasons upon the matter like another Solon]. Marmontel, Belisarius (London: printed for and sold by P. Vaillant; and by Robinson \& Co., 1767), 154. See also a comparison of a mentor with a gardener in François de Salignac de La Mothe Fénelon, The Adventures of Telemachus, the Son of Ulysses. Trans. Mr. Des Maizeaux, F. R. S. (revised). (London: Printed for T. Osborne, et al., [1767]), 199.

${ }^{81}$ This concept of a natural garden was promoted by John Locke, Joseph Addison, and Jean-Jacques Rousseau.

${ }^{82}$ "J'aime à la folie présentement les jardins à l'anglaise, les lignes courbes, les pentes douces, les étangs en forme de lacs, les archipels en terre ferme, et j'ai un profond mépris pour les lignes droites, les allées jumelles." Reddaway, ed., Documents of Catherine the Great, 163; Lentin, trans. \& ed., Voltaire and Catherine the Great, 137.
} 
emphasis on cultivation of natural shapes added a feminine touch to her civilizing projects. $^{8_{3}}$ The gardening activities presented another example of beneficial domesticity understood both privately and publicly and anticipated her reforms in education.

During her reign, Catherine II engaged in both private and public educational projects, performing the role of an exemplary grandmother, both real and figurative. ${ }^{84}$ Within her private household, the empress's views on gender and education remained strictly defined and conventional. She expressed a biased attitude to her granddaughters in her letter to Baron F. M. von Grimm of August 16, 1783, written after the birth of her first granddaughter Grand Princess Alexandra, admitting that she preferred boys to girls. ${ }^{85}$ Tellingly, Catherine's private projects focused on the preparation of her grandsons for state service. The royal grandmother wrote tales for Alexander and Constantine in which, among other things, she provided illustrations for her concept of justice. In the part of her primer entitled "Elementary Civic Education," she asserted that every tsar was expected to be fair to his subjects and not to take away their property even if their possessions appeared unbefitting. The clothing allegory depicted the surprise of Kir, the son of the Persian khan, at the appearance of two boys wearing unfitting caftans. When Kir suggested that they exchange their garments, his teacher explained that it was a tailor's job to decide on the size of the caftans. ${ }^{86}$ The tailor's job in Catherine's parable is analogous to that of a sovereign, whose authority should be obeyed and whose distribution of property should not be contested.

Catherine's policies with regard to her subjects' education concerned the formation of a new cultural elite. If Peter I stressed the acquisition of practical skills, Catherine II, in collaboration with Ivan Betskoi (1704-1795), and in line with contemporary scholarship on the subject, advocated the priority of spiritual and moral education. ${ }^{87}$ The empress's belief in the importance of social environment

\footnotetext{
${ }^{83}$ Dena Goodman has associated a power shift "from a weakened aristocracy to a triumphant monarchy" in France with the transition "from the sword to the pen." Goodman, Becoming a Woman in the Age of Letters, 7-8.

${ }^{84}$ On Catherine's engagement in education of her son and grandsons, see Black, Citizens for the Fatherland, 74-76, 130; Catherine's letters to Baron von Grimm, in Bartenev, ed., Russkii arkhiv 16.3 (1878): 73-76, 80, 82, 84-86, 90-91, 95, 104-105, 109, 117, 154, 186. On challenges of implementing educational programs, see N. P. Cherepnin, Imperatorskoe vospitatel'noe obshchestvo blagorodnykh devits (St. Petersburg: Gosudarstvennaia tipografiia, 1914-1915), 200-202, 226-37.

${ }^{85}$ See Catherine's letter to Baron von Grimm in Bartenev, ed., Russkii arkhiv 16.3 (1878): 92.

${ }^{86}$ Catherine II, Izbrannye sochineniia, 9-10.

${ }^{87}$ For a discussion of Catherine's interest in European works on education, particularly the pedagogical ideas of Montaigne, Comenius, Locke, Fénelon, and Montesquieu, see Black, Citizens for the Fatherland, 71-75. For a comparison of Betskoi's educational system with that of Locke, see Cherepnin, Imperatorskoe vospitatel'noe obshchestvo blagorodnykh devits, 1: 30-31, 37-42. On the strengthening of soul and body, giving priority to moral upbringing over acquisition of knowledge, and emphasis on public duty, see Michel de Montaigne, Essais de Michel Seigneur de Montaigne (London: J. Nourse, 1739), 1: 299-318; Helvétius, Oeuvres philosophiques, 4: 526-527, 531-535; on progression from physical to moral education and learning, see John Locke, Some Thoughts Concerning Education (1692) (Oxford: Oxford UP, 2000), 102-103, 128-33, 148, 152-58, 194, 207-208;
} 
for upbringing prompted her to organize several boarding schools, including a closed educational institution for girls from noble families-the Smolny Institute (1764). The empress deemed this cultural project useful for the state, and showcased it to Russian and European dignitaries as one of the achievements of her Enlightenment-oriented policies. Smolny's program of education combined both traditional and modern approaches. The institutional statute promoted a traditional ideal of domesticity. The goals of noblewomen's education were defined in the language similar to that of Domostroi and François Fénelon's Traité de l'éducation des filles [A Treatise on the Education of Daughters] (1687):

"We educate them [noblewomen] with a view to making them the delight of their future families; we want them to be neither prudes nor coquettes, but agreeable young ladies, capable of raising their own children and running their own homes." 88

The clauses deemed religion and ethics to be vital for a good upbringing, but in addition, placed emphasis on secular education, the acquisition of social graces, and household skills (including needlework). ${ }^{89}$ The course of studies was supposed to include a wide (for that time) range of social disciplines, sciences, and arts. Girls were encouraged to study foreign languages and geography, develop interest in reading historical and didactic literature, perform dramatic works both in their native and foreign tongues, but also to excel in dancing and drawing. Civility and neatness were regarded among the most crucial virtues, and were supposed to form regular mind-body practices for students. The young women graduating from the Smolny Institute were being prepared to perform their social duties at the court. Furthermore, the institution introduced a range of managerial responsibilities aimed at preparing its students for the tasks of running their own households and performing domestic roles. Students were expected to take care of institutional expenses and supplies, oversee the work in the kitchen, and

sections 30-31, 70, 90, 94, 134, 147; Black, Citizens for the Fatherland, 77; on the formation of mind and its enrichment with virtue, see Fénelon, Oeuvres, 1: 167-68. On the difference between Peter's and Catherine's approaches to education, see Vladimir Ia. Stoiunin, Pedagogicheskie sochineniia (St. Petersburg: Tipografiia Uchilishcha glukhonemykh, 1892), 106-107; 124-29, 136-37; Ivan M. Solov'ev, "Shkola Ekaterininskoi epokhi," in Iskiul', comp., Ekaterina II, 705-707; Pavel N. Miliukov, "Ocherki po istorii russkoi kul'tury," in Iskiul', comp., Ekaterina II, 717-18; Miliukov, "Educational Reforms," 93-95, 99; Black, Citizens for the Fatherland, 3, 7-8, 10, 91, 117. On the reassessment of educational goals by Catherine II in the eighties, see Miliukov, "Educational Reforms," 99.

88 "Nous les élevons (...) pour les rendre les délices des familles où elles entreront; nous ne les voulons ni prudes ni coquettes; mais aimables, et en état d'élever leurs enfants, d'avoir soin de leur maison."

See Catherine's letter to Voltaire of March 23 (April 3), 1772, Reddaway, ed., Documents of Catherine the Great, 16o; Lentin, ed. \& trans., Voltaire and Catherine the Great, 135. The ideal of domesticity was similar in the German burgher culture.

${ }^{89}$ For Catherine's commitment to secular education, see Madariaga, Politics and Culture in Eighteenth-Century Russia (London \& New York: Addison Wesley Longman, 1998), 184. 
participate in the education of younger girls. ${ }^{90}$ The rationale was twofold: to teach girls the skills of household economy and to nurture the perception of women as beneficial members of society and as figures of authority within social institutions (family, school, and the state). Maternal qualities and good citizenship were identified in the statute as the main assets in women's upbringing.

Catherine II personally attended to this civilizing project particularly in the earlier years, cultivating mother-daughter relationships with the students. She frequently visited the institution, corresponded with some of the girls, and invited many of them to court. The project was an attempt to educate noble girls in line with new pedagogical practices in Europe. Reality did not necessarily conform to the projected ideal, and the actual education acquired by the noble maidens was not as serious and intense as the statute deemed necessary. However, the Smolny Institute started to prepare girls for new social roles that were emerging at that time (the role of an educator, for example), ${ }^{91}$ and through her educational projects for women, the empress attempted to realize a culturally-approved and institutionalized vision of Enlightened womanhood and domesticity in new social contexts.

\section{Conclusion}

As this article has shown, during her reign, Catherine II employed various strategies to legitimize her authority as a female ruler, and was ultimately able to capitalize on what her contemporaries perceived as both masculine and feminine roles and behaviors. To gain the esteem of a more progressive part of Russian and European society, she highlighted her androgynous qualities, and promoted an image of an enlightened monarch. The projection of androgynous traits was particularly important during the first years of her reign, when her legitimacy and authority were seriously undermined. The empress tried to strengthen her authority during this period by emphasizing her patrilineal genealogy and respect for Peter I's political legacy. To promote the image of an enlightened monarch, Catherine II wrote her Great Instruction, created educational and cultural forums for her subjects, and publicized her policies abroad through correspondence with European philosophes. Yet, in contrast to Peter I, Catherine II relied on soft rather than hard power while implementing her policies, as she tried to create an inclusive, benevolent environment for her subjects. Her initiation of the cultural

\footnotetext{
${ }^{90}$ In A Treatise on the Education of Daughters, Fénelon discussed similar domestic and managerial responsibilities assigned to women. See François de Salignac de la Mothe Fénelon, Oeuvres ([Paris]: Gallimard, 1983), 1: 153-66. In Fonvizin's Minor (1782), Sophia, an ideal heroine for Catherine's educational projects, reads Fénelon's treatise.

${ }^{91}$ On the program of studies at Smolny Institute, see Polnoe sobranie zakonov Rossiiskoi imperii s 1649 goda (St. Petersburg: Tipografiia II Otdeleniia Sobstvennoi Ego Imperatorskogo Velichestva Kantseliarii, 1830), 16: 743-44, 750-51; Cherepnin, Imperatorskoe vospitatel'noe obshchestvo, 118-19; Black, Citizens for the Fatherland, 155-62.
} 
discussions in the periodicals of 1769-1774 is a good example of her employment of soft power.

To gain the approval of a more traditional part of society, the empress encouraged respect for homegrown traditions and cultivated a favorable view of her womanhood. She enhanced a positive attitude to her female authority by presenting herself as a woman of sense (in contrast to the image of a woman of fashion associated with Empress Elizabeth). In addition, she capitalized on the matriarchal qualities and domestic roles assumed within a household by eighteenth-century Russian women. These roles, while retaining their traditional qualities, gave women some authority within the household structure. By drawing upon the analogies between housecraft and statecraft and by presenting herself as a successful mistress of her "small household," the empress was able to mitigate her own and her populace's anxieties about a woman being in charge of the state. Taking on the cultural roles of a woman of merit-a matriarch, a craftswoman, a house manager, and an educator-enabled the empress to cultivate a positive attitude to her femininity, and ultimately to legitimize her authority as a female sovereign. As her reign progressed, Catherine's views on the relationship between gender and power as well as the resources she employed to maintain her authority as a female ruler underwent noticeable changes. She started to underscore the strengths of women's roles in society and demonstrated the ways in which these strengths could be cultivated and successfully employed in the management of the state. 